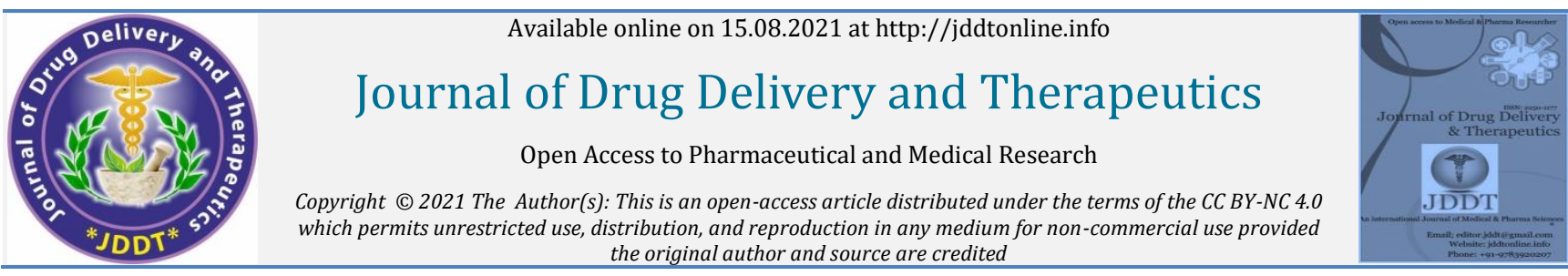

Open Access Full Text Article the original author and source are credited

Research Article

\title{
Formulation and Evaluation of Curcumin Gel Sanitizer
}

\author{
(D) Roja Maddi1 ${ }^{1}$, (DSurekha Perumalla², (D) Lalitha Kumari Sesham³, (DSeema Sultana Shaik4, (D)ithashma \\ Tanniru5 , (DHima Bindu Uppu6, DSri Lakshmi Kalasani7, Asiya Begum*, Rama Rao Nadendla9 \\ 1,2,3,4,5,6,7, Students, Department of Pharmaceutics, Chalapathi College of Pharmacy, Guntur, Andhra Pradesh, India
}

${ }^{8}$ Assistant professor, Department of Pharmaceutics, Chalapathi College of Pharmacy, Guntur, Andhra Pradesh, India

${ }_{9}^{9}$ Professor, Department of Pharmaceutics, Chalapathi College of Pharmacy, Guntur, Andhra Pradesh, India

\section{Article Info:}

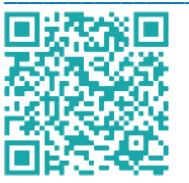

\section{Article History:}

Received 09 June 2021

Reviewed 21 July 2021

Accepted 28 July 2021

Published 15 August 2021

\section{Cite this article as:}

Maddi R, Perumalla S, Sesham LK, Shaik SS, Tanniru J, Uppu HB, Kalasani SL, Begum A, Nadendla RR, Formulation and Evaluation of Curcumin Gel Sanitizer , Journal of Drug Delivery and Therapeutics. 2021; 11(4-S):64-70

DOI: http://dx.doi.org/10.22270/jddt.v11i4-S.4985

*Address for Correspondence:

Asiya Begum, Assistant Professor, Department of Pharmaceutics, Chalapathi College of Pharmacy, Guntur, Andhra Pradesh, India

https://orcid.org/0000-0002-7714-6102

\section{Abstract}

Objective: the main intention of this research is to prepare a curcumin based herbal gel sanitizer by minimizing the alcoholic usage and to evaluate the anti-bacterial activity of this herbal sanitizer. Methods: curcumin gel sanitizer was prepared from the ethanolic extract of Curcuma longa along with addition of gel base prepared from the combination of carbapol940 and HPMC-E15. Results: The curcumin gel sanitizer was formulated and evaluated for its phytochemical constituents present in curcumin, detection of active constituent of curcumin which was majorly responsible for the anti-microbial activity through HPTLC, organoleptic properties, irritancy test and the efficiency of anti-bacterial activity of curcumin was also evaluated and it is safe and effective against pathogens. Conclusion: As a natural herb, curcumin which was a household ingredient could also be effectively formulated as a sanitizer that reduces the side effects of alcoholic sanitizer products and is a best source that acts effectively against a numerous pathogens.

Keywords: curcumin, carbapol-940, Ethanolic extract, HPMC-E15 (hydroxypropyl methylcellulose), HPTLC, Pathogens,

\section{INTRODUCTION}

Corona virus is a single-stranded RNA virus with a diameter of about $80-120 \mathrm{~nm}$. It belongs to different genus like $\alpha$ corona virus, $\beta$-corona virus, $\delta$-corona virus and $\gamma-$ corona virus. SARS-CoV- 2 comes under the genus $\beta$-corona virus. ${ }^{4}$ The emergence of the pandemic COVID-19 has lead to health concern in the public and rapid usage of hand sanitizers is being observed. ${ }^{3}$ As it can be effective tool of controlling the infection. Recent studies revealed that the transmission of COVID is possible through the mist and the virus can sustain and may become contagious on surfaces about 9 days 2 . Hence, it is very important to breakout this conveyance of virus through isolation and by the usage of infection control tools ${ }^{3}$. Effective usage of hand sanitizers and face masks could minimize the spread of the virus. According to the analysis of CDC about 2 million people are getting affected by certain infections acquired through the hospitals per year 12 . Due to danger imposed by this disease, the CDC of the United States has encouraged and promoted the hand sanitizers usage for the sake of maintenance of hand hygiene ${ }^{12}$. The availability of Hand disinfectants are in such forms like Nonalcohol based, alcohol-based, herbal sanitizers ${ }^{15}$.

Hand sanition is a crucial step in controlling the infectious virus in the healthcare systems. ${ }^{9}$ Numerous hand-sanitation products were accessible outside as they became an emergent rise for the maintanance of hand-hygiene can be seen ${ }^{14}$. Besides regular soaps, hand sanitizers which consists of different chemical agents with effective anti-microbial properties(such as chlorhexidine, iodophors, quaternary ammonium compounds, triclosan) without the use of water or hand drying materials are used rapidly these days. ${ }^{3}$

Alcoholic formulations are very effective in various situations. They exterminate various types of pathogens ${ }^{8}$ but they are not much efficacious in eradicating the organisms such as Clostridium difficile or Bacillus anthracis. In addition rapid usage of these alcohol-based sanitizers can cause flammability, endocrinal disruptions etc. ${ }^{1}$ Moreover the culture of intentional ingestion of alcohol-containing sanitizers has become popular during this pandemic. ${ }^{1}$

This brings out the case of non-alcohol based sanitizers or herbal based sanitizers which is becoming an option. Medicinal plants consist of abundant secondary metabolites, such as tannins, terpenoids, alkaloids and flavonoids, as these are found to possess greater anti-microbial activity ${ }^{16}$. Taking this into consideration, the literature screening was performed for different herbs with the anti-microbial properties and founded them (such as Curcuma longa (turmeric), Mentha piperita (peppermint leaves), Eugenia caryophyllus (clove flower buds), and Azadirachta indica 
(neem leaves) ${ }^{7}$. Before the discovery of advanced medicine, herbs are the crucial remedy used for various disease treatments. This arrivals of different antibiotics; microbes begin to develop resistance to these antibiotics. This brings the researchers towards the herbs those are abundant in microbial activity. ${ }^{15}$

This research is carried out by formulating an herbal sanitizer with the extract of Curcuma longa. The ethanolic extract of turmeric has strong anti-microbial properties against the growth of certain microbes such as Pseudomonas aeruginosa, Bacillus cereus and Proteus mirabilis. It also has good anti-fungal activity against Trichophyton longifusus. External application of curcumin was found to decrease variegation and onset of skin tumors. ${ }^{7}$

\section{MATERIALS AND METHODS:}

\section{Plant material processing:}

Newly harvested rhizomes of curcumin are collected, cleaned and dried under sunlight. The rhizomes after the process of drying were collected and size reduced bypassing through the mesh of suitable size. ${ }^{2}$

\section{EXTRACTION PROCESS:}

Powdered rhizomes of curcumin were extracted with 95\% ethanol through the process of maceration for about 24 hours. The obtained crude extract was filtered, concentrated and collected.

\section{PRELIMINARYPHYTOCHEMICAL ASSESSMENT OF CRUDE EXTRACT:}

The prepared curcumin extract was assessed for the presence of different phytoconstitutents such as carbohydrates, proteins, alkaloids, flavonoids, tannins and saponins using standard preliminary tests.

CARBOHYDRATES: The curcumin extract is dissolved in $10 \mathrm{ml}$ of purified water, filtered and was subjected to the tests for carbohydrates. ${ }^{17}$

Molisch test: $2 \mathrm{ml}$ of curcumin extract was added into the test tube and few drops of molisch reagent was added to extract. To this $2 \mathrm{ml}$ of conc. $\mathrm{H}_{2} \mathrm{SO}_{4}$ was dropped out from the walls of the test tube. Formation of a violet color ring at the junction of two liquids was observed. ${ }^{17}$

PROTEINS: The processed curcumin extract was dissolved in $10 \mathrm{ml}$ of water, filtered and test for proteins was carried out. 17

Biuret test: $2 \mathrm{ml}$ of filtered solution is treated using a drop of $2 \%$ copper sulphate solution. Later on addition of few drops of ethanol (95\%). Followed by the addition excess of potassium hydroxide pellets. Pink color formation in ethanolic layer indicates the protein presence. ${ }^{17}$

ALKALOID: the solvent free extract of required ${ }^{17}$ quantity was added to $3 \mathrm{ml}$ of dilute HCL and then filtered. The filtrate was then carried out for the test of alkaloids. ${ }^{17}$

Mayer's test: To $1 \mathrm{ml}$ of filtered extract 2 drops of Mayer's reagent is added from the walls of the test tube. The presence of white or creamy precipitate includes for the alkaloid presence. ${ }^{17}$

Wagner's test: To $1 \mathrm{ml}$ of filtrate $2 \mathrm{ml}$ of Wagner's reagent was added from the walls of the test tube.Presence of reddish-brown precipitate confirm positive for the above test. [ 17

Dragendroff's test: To the $1 \mathrm{ml}$ of filtered extract $2 \mathrm{ml}$ of Dragendroff's reagent is added. Formation of yellow color precipitate confirms were positive test ${ }^{17}$.

\section{GLYCOSIDES}

Borntrager's test: Prepared curcumin extract was boiled with dilute $\mathrm{H}_{2} \mathrm{SO}_{4}$, filtered and the addition of chloroform was done and shaken well. The separation of organic layer was observed to which ammonia is added slowly. The appearance of pink or red color in ammonical layer indicates positive for the test. ${ }^{13}$

\section{TERPENOIDS}

Salkowski test: To the extract add $2 \mathrm{ml}$ of chloroform and $3 \mathrm{ml}$ of concentrated $\mathrm{H}_{2} \mathrm{SO}_{4}$ was added carefully. A reddish brown color formation indicates presence of terpenoids. ${ }^{13}$

FLAVONOIDS: To the extract $1.5 \mathrm{ml}$ of $50 \%$ methanol was slowly added. The above solution is warmed and magnesium metal was added onto it. To this, addition of concentrated sulphuric acid and red color was observed indicating for the presence of flavonoids. ${ }^{13}$

TANNINS: To $0.5 \mathrm{ml}$ of extract, water and few drops of ferric chloride was added. Presence of blue color indicates for tannins presence. ${ }^{13}$

SAPONINS: The processed curcumin extract was shaken with $5 \mathrm{ml}$ of water and then heated for boil. Frothing shows up for saponins presence. 17

\section{ASSESSMENT OF ISOLATED CURCUMIN BY HIGH PERFORMANCE THIN LAYER CHROMATOGRAPHY}

\section{EXPERIMENTAL:}

Extraction of the curcuminoid from Curcuma longa was carried out with two different solvents and then the isolation of curcumin from the other two components of curcuminoid. 5

Preparation of sample: $0.5 \mathrm{gm}$ of Curcuma longa was dissolved in $10 \mathrm{ml}$ of ethanol, filtered, concentrated and was collected.

Developing system: Ethyl acetate: n-hexane 3:7 solvent system was made into use for the development of HPTLC fingerprint profile of terpernoids.

Sample application: Test solution of the curcumin extract $(2 \mu l)$ and standard solution of the standard curcuminoid extract $(3 \mu \mathrm{l})$ were filled in Hamilton syringe for $5 \mathrm{~mm}$ band length on percoated silica gel $\mathrm{G}$ aluminum plate $60 \mathrm{~F} 254$ (E MERCK Germany) $(3 \times 10 \mathrm{~cm})$ using the applicator connected to AETRON HPTLC system installed and programmed with SPRAYLIN.

Development of chromatogram: The developed chromatogram was dried at room temperature and then placed in AETRON document chamber and visualized less than $254 \mathrm{~nm}$ and image of the chromatogram were obtained with an EOS utility, after quantification was done by using the SPRAYLIN software.

\section{FORMULATIONS}

\section{Trail No-1}

Ethanolic extract of Curcuma longa was prepared by the process of maceration for about 72 hours. A gel base was prepared using carbapol and water and transferred into the motor. Filtrate was then added into the motor along with the other ingredients. At last triethanolamine was added and transferred into a bottle.The ingredients were listed in the below table(I)

\section{Trail No-2}

Ethanolic extract of Curcuma longa was prepared by the process of maceration for about $24 \mathrm{hrs}$. The preparation of gel 
base was achieved by the combination of carbapol-940 and HPMC-E15 in water followed by the addition of $\mathrm{NaOH}$ and This gel base was transferred into motor and the herbal extract was added along with the other ingredients and transferred into suitable container. The ingredients were listed in the below table(II)

\section{Trail No-3}

Herbal extract of Curcuma longa was prepared using ethanol (95\%) as a solvent. Gel base was prepared using the combination of Carbapol-940 and HPMC-E15 at the ration of $4: 1$. The prepared gel base was neutralized using $\mathrm{NaoH}$ $(10 \%)$ which also acts as a cross linking agent. This gel base was transferred to motor and the herbal extract was added one after the other. The remaining ingredients were added onto the motor and then transferred into clear container. The ingredients were listed in the below table(III).

Table 1: List of ingredients

\begin{tabular}{|l|l|l|}
\hline S.No & Ingredients & Quantity (\%) \\
\hline 1. & Curcuma longa & 1 \\
\hline 2. & Neem oil & q.s \\
\hline 3. & HPMC-E15 & 0.1 \\
\hline 4. & Carbapol-940 & 0.4 \\
\hline 5. & Triethanolamine & 1 \\
\hline 6. & Glycerin & 5 \\
\hline 7. & Perfuming agent & q.s \\
\hline 8. & Water & q.s \\
\hline
\end{tabular}

Table 2: List of ingredient

\begin{tabular}{|l|l|l|}
\hline S.No & Ingredients & Quantity Taken (\%) \\
\hline 1. & Curcuma longa & 2 \\
\hline 2. & Neem oil & q.s \\
\hline 3. & Carbapol-940 & 0.4 \\
\hline 4. & HPMC-E15 & 0.1 \\
\hline 5. & NaoH & 10 \\
\hline 6. & Perfuming agent & q.s \\
\hline 7. & Water & q.s \\
\hline
\end{tabular}

Table 3: List of ingredients

\begin{tabular}{|l|l|l|}
\hline S.No & Ingredients & Quantity (\%) \\
\hline 1. & Curcuma longa & 5 \\
\hline 2. & Neem oil & q.s \\
\hline 3. & Carbapol-940 & 0.4 \\
\hline 4. & HPMC-E15 & 0.1 \\
\hline 5. & NaoH & 10 \\
\hline 6. & Glycerin & 5 \\
\hline 7. & Perfuming agent & q.s \\
\hline 8. & Water & q.s \\
\hline
\end{tabular}

\section{RESULTS AND DISCUSSION:}

\section{RESULTS:}

\section{PHTOCHEMICAL SCREENING}

The phytochemical evaluation of ethanolic extract of curcumin results for the existence of secondary metabolites such as carbohydrates, proteins, alkaloids, terpenoids, tannins and flavonoids but the absence of saponins and glycosides. These secondary metabolites serve as competitive weapons against the bacteria, fungi, amoebae and insects.

Table 4: The evaluated phytochemical constituents were listed in the below Table NO-04

\begin{tabular}{|l|l|c|}
\hline S.No & Test & Observation \\
\hline 1. & Carbohydrates & + Ve \\
\hline 2. & Proteins and amino acids & + Ve \\
\hline 3. & Alkaloids & + Ve \\
\hline 4. & Glycosides & - Ve \\
\hline 5. & Terpenoids & $+\mathrm{Ve}$ \\
\hline 6. & Tannins & $+\mathrm{Ve}$ \\
\hline 7. & Saponins & $+\mathrm{Ve}$ \\
\hline 8. & Flavonoids & $+\mathrm{Ve}$ \\
\hline
\end{tabular}

\section{HIGH PERFORMANCE THIN LAYER CHROMATOGRAPHY OF ISOLATED CURCUMIN}

Linear ascending development to a distance of $80 \mathrm{~mm}$ using the n-hexane and ethyl acetate as mobile phase was carried out in a twin trough glass chamber formerly saturated with the mobile phase vapour for $20 \mathrm{~min}$. Plates were dried in air and photo documented at $\lambda 254 \mathrm{~nm}$ and $\lambda 365 \mathrm{~nm}$. Results obtained at $365 \mathrm{~nm}$ were taken out. ${ }^{1}$

The turmeric (diferuloylmethane) was a polyphenolic compound consists of the active constituents responsible for the anti-bacterial, anti-fungal,anti-oxidant,anti-proliferative activity such as curcumin, bisdemethoxy curcumin, demethoxycurcumin, curcuminoids e.t.c.

The scan of reference solution revealed the Rf value of 0.68 for the standard and for the test sample it is 0.79 . Therefore, the HPTLC evaluation of C.long depicts the presence of the active constituent curcumin in the ethanolic extract of C.longa. ${ }^{18}$. The standard reference values for the active constituents of curcumin were provided in the below table05 .

Table 5: The standard reference values for the active constituents of curcumin

\begin{tabular}{|l|l|l|}
\hline S.No & Standard & $\operatorname{Rf}(\mathrm{cm} / \mathrm{cm})$ \\
\hline 1. & Curcumin & $0.69-0.88$ \\
\hline 2. & Demethoxycurcumin & $0.56-0.69$ \\
\hline 3. & Bisdemethoxycurcumin & $0.38-0.56$ \\
\hline
\end{tabular}




\section{SAMPLE CURCUMIN}

Plate

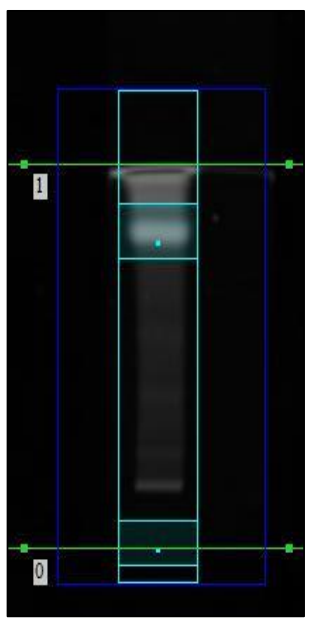

Graph

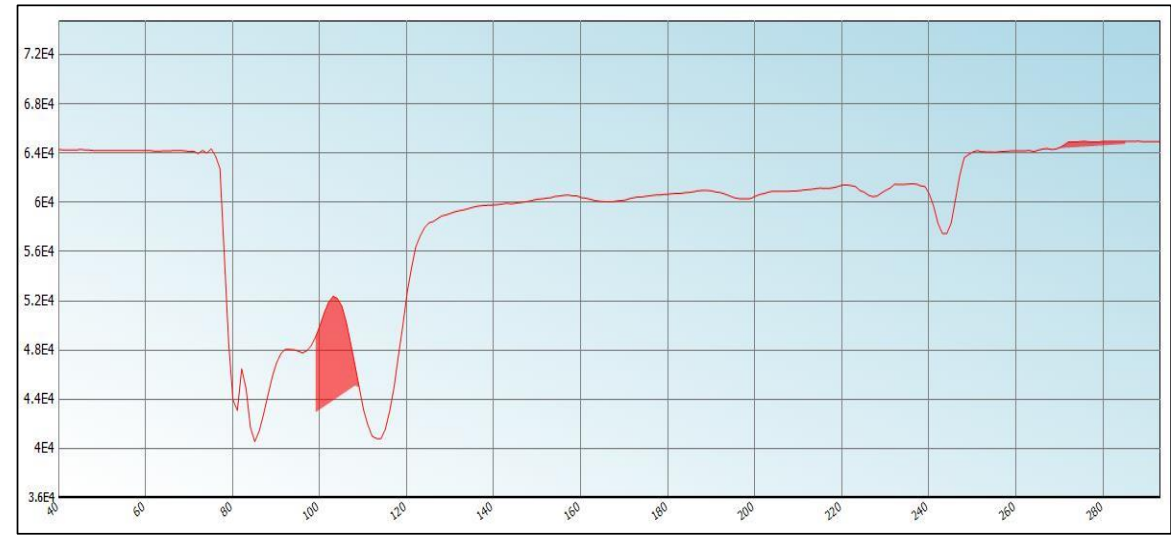

Lanes

\begin{tabular}{|l|l|l|l|l|}
\hline ID & Width & Bands & Volume & Notes \\
\hline 1 & 49 & 2 & 16.36 & \\
\hline
\end{tabular}

Bands

\begin{tabular}{|l|l|l|l|l|}
\hline ID & Rf & Area & Volume & Notes \\
\hline 1 & 0.793 & 1372 & 14.2 & \\
\hline 2 & 0 & 1127 & 2.16 & \\
\hline
\end{tabular}

\section{STANDARD CURCUMIN}

Plate

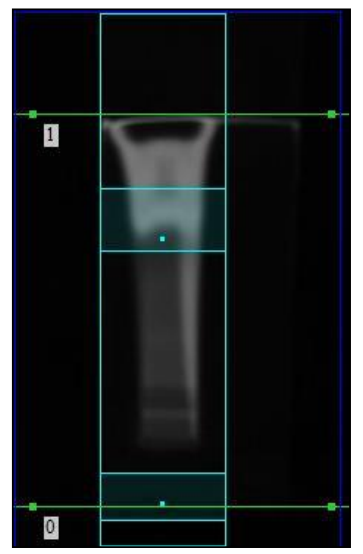


Graph

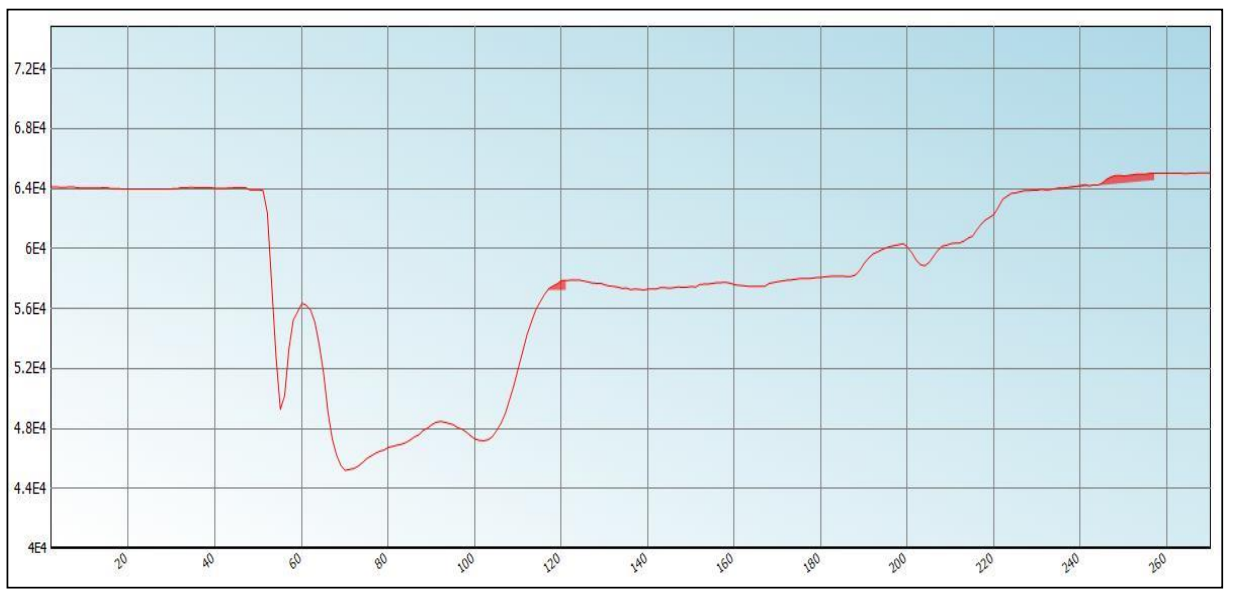

Lanes

\begin{tabular}{|l|l|l|l|l|}
\hline ID & Width & Bands & Volume & Notes \\
\hline 1 & 66 & 2 & 3.93 & \\
\hline
\end{tabular}

Bands

\begin{tabular}{|l|l|l|l|l|}
\hline ID & Rf & Area & Volume & Notes \\
\hline 1 & 0.682 & 2046 & 0 & \\
\hline 2 & 0.005 & 1584 & 3.93 & \\
\hline
\end{tabular}

\section{Evaluation Parameters:}

Organoleptic properties: The color, odour and clarity of the formulation were carried out. 6

pH: $\mathrm{pH}$ of sanitizer was carried out through $\mathrm{pH}$ meter and it was observed that the $\mathrm{pH}$ of sanitizer was optimum that is exactly 6.9.

Skin Irritant test: Few healthy Volunteers were selected. The formulated curcumin sanitizer was applied on their palm and the time was noted down. Irritancy and itching were checked. ${ }^{11}$

Evaporation time: Few healthy Volunteers were selected. The curcumin sanitizer was applied on their palm and the time of evaporation was noted down. All the evaluated parameters were provided in the below table-06

Evaluation of anti-bacterial activity: The evaluation of anti-bacterial activity of curcumin gel sanitizer was carried out using different solvents against the strain of aerobic and anaerobic micro-organisms by performing cup-plate method. The nutrient agar medium used for the culture media was provided in the below table-07.

To perform the test, the Petri-plates required for the test must be pre-sterilized to avoid cross-contamination. Petriplates were pre-sterilized at $160^{\circ} \mathrm{C}$ in hot air oven. Then, Prepared nutrient agar medium was autoclaved at $121^{\circ} \mathrm{C}$ for about 30minutes. Under aseptic conditions culture media was transferred into nutrient agar medium and this entire media is transferred into petri-plate. After, uniform spreading the petriplates were kept aside in until the medium gets solidified.

Table 6: Composition of nutrient agar medium

\begin{tabular}{|l|l|l|}
\hline S.No & Ingredients & Quantity(g) \\
\hline 1. & Beef extract & 0.2 \\
\hline 2. & Yeast extract & 0.4 \\
\hline 3. & Peptone & 1 \\
\hline 4. & Sodium chloride & 1 \\
\hline 5. & Agar & 1.5 \\
\hline 6. & Distilled water & q.s for $100 \mathrm{ml}$ \\
\hline
\end{tabular}

Then, the plates were taken out and cups or wells were made by using cork borer. Then, the standard 95\% ethanolic extract of turmeric and the test sample was added into the cup carefully in aseptic conditions. Then both the plates are incubated for $24 \mathrm{hrs}$ at $37^{\circ} \mathrm{C}$. After, the incubation period, the zone of inhibition was measured on the Petri plate.

The anti-bacterial evaluation of the formulated curcumin gel sanitizer was found to be safe and effective against the bacterial species such as E.coli and Bacillus subtilis. As it can be seen that anti-microbial effect of curcumin sanitier is more efficacious in inhibiting the growth of the microbes as that of the standard i.e ethanolic extract of turmeric. The results were provided in the below table- 08 . 
Table 7: Anti-bacterial evaluation of curcumin gel sanitizer

\begin{tabular}{|l|l|l|l|}
\hline S.No & Anti-bacterial test & Zone of inhibition(Standard)-mm & Zone of inhibition(Formulation)-mm \\
\hline 1. & E.coli & 18 & 15 \\
\hline 2. & B.subtilis & 14 & 11 \\
\hline
\end{tabular}

Table 8: Evaluation parameters

\begin{tabular}{|l|l|l|}
\hline S.No & Parameter & Formulation \\
\hline 1. & Color & Lemon yellow \\
\hline 2. & Odour & characteristic \\
\hline 3. & $\mathrm{pH}$ & 6.9 \\
\hline 4. & Irritancy test & No irritation \\
\hline 5. & Evaporation rate & 20seconds \\
\hline
\end{tabular}

\section{DISCUSSION}

The curcumin gel hand sanitizer was evaluated for its phytochemical screening of active constituents, and also the determination of active constituent of curcuma nothing but curcumin through HPTLC and evaluation of organoleptic properties of the formulated herbal gel sanitizer and checked for the irritancy test and the evaporation time. It was found that the above formulation consist of the lemon yellow colour with the gel consistency and smooth texture. It was also tested for its anti-microbial activity against E.coli and B.subtilis and has shown a significant effect against these microbes. The above formulation consists of the ethanolic herbal extract to minimize the alcohol usage in the formulation of the herbal sanitizer.

\section{CONCLUSION}

Hands are the common platform for the pathogenic transmission to the people. The proper maintenance of hand hygiene can protect the health from various contagious pathogens especially for the prevention of COVID-19 transmission. WHO recommendation for the usage of alcohol based-sanitizers during this pandemic for the prevention of the disease transmission. But the rapid usage of these alcohol-based sanitizers causing the endocrinal disruptions, flammability and alcohol poisoning if ingested and the intentional ingestion of alcohol containing sanitizers all these were major cases to be considered.

It may be concluded that curcumin gel sanitizer has a significant role as it shows significant effect against specified organisms. Thus, there is immense care in establishing the usage of turmeric gel sanitizer as a measure to control the multi-drug resistant microbes. This herbal gel sanitizer is also based as an alternative for the chemically prepared sanitizers containing active silver nitrates. Natural herbal sanitizers are very efficacious, environmental friendly, and inexpensive.

The above formulation can be use as good sanitizer as the Curcuma longa is much effective against pathogens and its shows effective anti-bacterial activity as a herbal gel sanitizer.

\section{ACKNOWLEDGEMENT}

The authors are grateful to the management of chalapathi institute of pharmaceutical sciences for providing all the necessary facilities for the successful completion of the work.

\section{CONFLICT OF INTEREST}

The authors declare no conflict of interest.

\section{ABBREVIATIONS}

HPMC (hydroxyl propyl methyl cellulose), HPTLC (high performance thin layer chromatography), CDC (centre for disease control and prevention).

\section{REFERENCES}

1. Singla D, Saini K. Formulation of an Herbal Substitute for Chemical Sanitizer and its Evaluation for Antimicrobial Efficiency. International Journal of ChemTech Research. 2019; 12(3):11420. https://doi.org/10.20902/IJCTR.2019.120318

2. Nandini N. Herbal hand Sanitizer for management of Indoor bioaerosol and touch surfaces. Journal of Pharmacognosy and Phytochemistry. 2020; 9(3):1171-5.

3. Jing JL, Pei Yi T, Bose RJ, McCarthy JR, Tharmalingam N, Madheswaran T. Hand sanitizers: a review on formulation aspects, adverse effects, and regulations. International journal of environmental research and public health. 2020 Jan; 17(9):3326. https://doi.org/10.3390/ijerph17093326

4. Chakraborty A, Mukhopadhyay A, Sur A, Ghosh S. Production of cheap hand sanitizer with herbal ingredients. InJournal of Physics: Conference Series 2021 Feb 1 (Vol. 1797, No. 1, p. 012036). IOP Publishing. https://doi.org/10.1088/17426596/1797/1/012036

5. Nurjanah N, Saepudin E. Curcumin isolation, synthesis and characterization of curcumin isoxazole derivative compound. InAIP Conference Proceedings 2019 Nov 4 (Vol. 2168, No. 1, p. 020065). AIP Publishing LLC.

https://doi.org/10.1063/1.5132492

6. Harismah K, Ariningrum ND, Fuadi AM, Mujiburohman M, Mirzaei M. Formulation and Evaluation of Herbal Hand Sanitizer Based on Stevia (Stevia rebaudiana). InJournal of Physics: Conference Series 2021 Apr 1 (Vol. 1858, No. 1, p. 012053). IOP Publishing. https://doi.org/10.1088/1742-6596/1858/1/012053

7. Alghamdi HA. A need to combat COVID-19; herbal disinfection techniques, formulations and preparations of human health friendly hand sanitizers. Saudi Journal of Biological Sciences. 2021 Apr 9. https://doi.org/10.1016/j.sjbs.2021.03.077

8. Thorat Y, Kumbhar S, Matole V, Birajdar A, Madur S, Patil S, Shegaonkar A. Formulation and Evaluation of Neem extract Hand Sanitizer. Asian Journal of Pharmacy and Technology. 2020 Sep 1; 10(3). https://doi.org/10.5958/22315713.2020.00023.9

9. Sharma SK, Rahat I. Oregano Derived Anti-Bacterial Hand Sanitizer: Formulation and Characterization. Journal of Pharmaceutical Research International. 2020:64-72. https://doi.org/10.9734/jpri/2020/v32i3931025

10. Osei-Asare C, Oppong EE, Apenteng JA, Adi-Dako O, Kumadoh D, Akosua AA, Ohemeng KA. Managing Vibrio cholerae with a local beverage: preparation of an affordable ethanol based hand sanitizer. Heliyon. 2020 Jan 1; 6(1):e03105. https://doi.org/10.1016/j.heliyon.2019.e03105

11. Suryawanshi VR, Surani HC, Yadav HR. Formulation, evaluation and anti-microbial efficiency of alcohol based herbal hand sanitizer. Int J Eng Sci Comput. 2020; 12:25113-15.

12. Balkrishna A, Singh K, Singh H, Haldar S, Varshney A. GermiX: A skin friendly hand sanitizer with prolonged effectivity against 
pathogenic bacteria. AMB Express. 2020 Dec; 10(1):1-8. https://doi.org/10.1186/s13568-020-01151-y

13. Govindwar MN. Phytochemical and Antibacterial Evaluation of Formulated Hand Sanitizer from different Natural Sources and Waste materials.

14. Azad MM, Al Mahmud A, Islam MS, Gouhar AI. Common sage (Salvia officinalis) antiviral role: potentiality of a Unani hand sanitizer in COVID-19 (corona virus) second wave control. Asian Journal of Medical and Biological Research. 2020; 6(4):611-7. https://doi.org/10.3329/ajmbr.v6i4.51225

15. Subramanian A. Case Study Testing the Antibacterial Efficacy Between Alcohol-Based and Alcohol-Free Sanitizer on the Human Hand. June 23, 2020.

16. Ranganathan V, Kumar PS, Vijayakaran K, Elamaran A. Evaluation of curcumin compound from methanolic extracts of
Curcuma longa by high performance thin layer chromatography. Journal of Pharmacognosy and Phytochemistry. 2020; $9(2): 1931-4$

17. Asati S, Chandel V, Choubey A. extraction and comparative study on physico-chemical, phytochemical analysis of fruits of Terminalia chebula and rhizomes of Curcuma longa. Plant Archives. 2020; 20(2):4289-94.

18. Bhogaonkar MD. HPTLC fingerprinting of phenolics profile of three Curcuma species; Vol. 8, Issue 2, Part B (2020)

19. Shaikh F, Bhosale P, Snehal. Formulation and Evaluation of Herbal Hand Sanitizer Using Psidium guajava Leaves Extract. International Journal of Pharmaceutical Sciences Review and Research. 2020; 62(2):37-39. 